\section{In vitro cloning of Bambusa pallida Munro through axillary shoot proliferation and evaluation of genetic fidelity by random amplified polymorphic DNA markers}

\author{
Beena D.B., ${ }^{1,2}$ Rathore T.S. ${ }^{2,3}$ \\ 1'Department of Biotechnology, CMR \\ Institute of Management Studies, Kalyana \\ Nagar, Bangalore; ${ }^{2}$ Institute of Wood \\ Science and Technology, Malleswaram, \\ Bangalore; ${ }^{3}$ Arid Forest Research \\ Institute, Jodhpur, Rajashtan, India
}

\section{Absract}

Multiple shoots emerged from the nodal shoot segments of the field-grown candidate plus clump explants of Bambusa pallida Munro when cultured on Murashige and Skoog (MS) liquid medium with additives (ascorbic acid 50 $\mathrm{mg} / \mathrm{L}+$ citric acid $25 \mathrm{mg} / \mathrm{L}$ + cysteine $25 \mathrm{mg} / \mathrm{L}$ ) and combined use of $\alpha$-naphthalene acetic acid (NAA) $1.34 \mu \mathrm{M}+$ thiodiozuron $1.125 \mu \mathrm{M}$ in a 2 -week period. Further shoot multiplication was achieved in MS liquid medium with additives + NAA $1.34 \mu \mathrm{M}+6$-benzylaminopurine $4.4 \mu \mathrm{M}$ at $25 \pm 2{ }^{\circ} \mathrm{C}$ and $33.78 \mu \mathrm{mol}$ photons $\mathrm{m}^{-2} \mathrm{~s}^{-1}$ light illumination for a 12 -h photoperiod. These shoots were rooted within four weeks in MS/2 basal salt medium with additives $+2 \%$ sucrose $+1 \%$ glucose, and $0.6 \%$ agar by pulse treatment of shoots with indole 3 butyric acid $0.5 \mathrm{mg} / \mathrm{mL}$ for $30 \mathrm{~min}$ prior to inoculation. Rooted plants were successfully hardened in the mist chamber. Survival rate during hardening was more than 95\%. Micropropagated plants achieved a height of 25-30 cm with 3-4 tillers (shoots) with miniature rhizome in a 4-month period. Genetic stability was observed in the micropropagated plants.

\section{Introduction}

Bambusa pallida Munro is one of the most industrially important bamboo species. It is distributed in India and Burma. In India, it is found in Arunachal Pradesh, Nagaland, Mizoram, Tripura, Assam, North Bengal, Meghalaya, Sikkim and Myanmar. ${ }^{1}$ It naturally occurs on gentle slope at altitudes up to $2000 \mathrm{~m}$ and in the plains. It is cultivated in the planes, mostly in North-Eastern India. Culms are green and are covered with white powder. They are $13-20 \mathrm{~m}$ height with a diameter of 5.0-8.0 cm. Bambusa pallida Munro is mainly used to build homes, and make baskets, mats, toys, wall plates, screens and wall hangers. In addition, it is one of the most important bamboos used in the pulp and paper industry. ${ }^{2}$ From a commercial point of view, it is one of the 14 most important bamboo species selected by the National Mission on Bamboo Applications because of its high tensile strength and it is considered an important vehicle for widespread and sustainable development. The Food and Agricultural Organization has reported that its young juvenile shoots are rich in calcium, vitamin, cellulose, amino acids and other trace elements, and it is commonly eaten as a vegetable in the local community. Charcoal from $B$. pallida provides effective adsorbents to remove iron from water. ${ }^{3}$ Leaf and leaf sheath litter decay of these species are a good source of carbon, nitrogen and lignin. ${ }^{4}$ It has a wide range of applications, and ever increasing demand and unsuccessful attempts to replenish cultivation following indiscriminate overexploitation are resulting in severe depletion of wild stock. A long flowering cycle (40 years) and the low success rate of propagation through culm cuttings are the main problems associated with conventional methods of propagation of the species. ${ }^{5,6}$ Since the gap between demand and supply of bamboo is widening, plant tissue culture-based biotechnological tools provide scope for rapid and mass production of clonal planting material of candidate plus clumps, quickly improving rejuvenation. The main disadvantages of the use of seedling material are insufficient or no knowledge of genetic background, restricted availability, and rapid loss of germination. The problems associated with adult bamboos are endogenous contamination, hyperhydricity, instability of multiplication rate at initial stage, poor rejuvenation, and low rate of rooting. ${ }^{7}$ Although management of adult tissues is difficult, micropropagation through axillary shoot proliferation is considered safer and a preferred method for the commercial propagation of hardwoods because it maintains genetic stability better than propagation by organogenesis. ${ }^{8}$ Superior genotypes (Candidate Plus clumps) of $B$. pallida have been selected by the Arunachal Pradesh Forest Research Institue, Itanagar, North Eastern India, based on the morphological traits as well as by the Rain Forest Research Institute, Jorhat. $^{9}$ In vitro propagation of bamboo through axillary shoot proliferation from mature clumps has been reported in Dendrocalamus strictus, Bambusa edulis, D.brandisii, D.giganteus, Pseudoxyte nanthera stocksii, Bambusa balcoa, Guadua angustifolia and B.glaucescens. ${ }^{10-17}$ However, use of tissue culture as a continuous source of disease-free planting material for commercial purposes and periodic monitoring of the degree of genetic stability among in svitro grown plantlets are of utmost importance. The
Correspondence: Beena D.B, Assistant Professor, Department of Biotechnology, CMR Institute of Management Studies C.A\#2, 3rd C Cross, 6th A Main, HRBR Layout, 2nd Block, Kalyana Nagar, Bangalore- 560 043. Karnataka, India.

Tel. +91.9844760457

E-mail: beena2631@yahoo.com

Key words: Bambusa pallida, in vitro rooting, bamboo, genetic fidelity.

Acknowledgments: Department of Biotechnology, Government of India, New Delhi is gratefully acknowledged for their financial support to carry out the present study. The authors also wish to thank the Director, IWST, Bangalore for providing facilities. Our special thanks to Arunachal Pradesh State Forest Institute, Itanagar and Rain Forest Research Institute, Jorhat, for providing the genetically superior offset cuttings of $B$. pall$i d a$ for this work.

Conflict of interests: the authors report no conflict of interests.

Received for publication: 17 January 2012.

Revision received: 18 June 2012.

Accepted for publication: 22 June 2012.

This work is licensed under a Creative Commons Attribution NonCommercial 3.0 License (CC BYNC 3.0).

(C) Copyright Beena DB and Rathore TS, 2012 Licensee PAGEPress srl, Italy

International Journal of Plant Biology 2012; 3:e6 doi:10.4081/pb.2012.e6

chances of somaclonal variation at early or late phase of culture can be minimized by regular assessment of genetic stability.Various molecular tools, such as Random Amplified Polymorphic DNA (RAPD), Restricted Fragment Length Polymorphism (RFLP), Amplified Fragment Length Polymorphism (AFLP) and Inter Simple Sequence Repeats (ISSR) markers, are available to assess variability. Among these, RAPD is the simplest and cheapest for analysis of genetic fidelity of in vitro propagated plants. ${ }^{18-20}$ There are no reports of micropropagation of $B$. pallida. This is the first report on in vitro cloning of $B$. pallida through axillary shoot proliferation from the explants of superior genotypes of mature clumps and evaluation of genetic fidelity of micropropagated plants through RAPD analysis.

\section{Materials and Methods}

\section{Collection, processing and surface sterilization}

Offset cuttings of superior genotypes (Candidate Plus Clumps) of Bambusa pallida 
were collected from the germplasm bank of the State Forest Research Institute, Itanagar, and the Rain Forest Research Institute, Jorhat (Figure 1A). These genotype offset cuttings were planted in gunny bags with sand, soil and compost $(6: 1: 3, \mathrm{v} / \mathrm{v})$ and kept in a greenhouse at $85 \%$ RH for new shoot growth and root development. After proper hardening, the plants were transplanted to the bamboo germplasm bank, Gottipura, Bangalore, while a few plants were kept at the Institute of Wood Science and Technology (IWST) nursery (Figure 1B) as explant for micropropagation studies. The shoots of newly grown culm branches were collected from the germplasm bank and the IWST nursery. Culm sheath was removed after swabbing the surface of shoots with $70 \%(\mathrm{v} / \mathrm{v})$ ethanol. Explants were excised into single nodal segments 2.5-3.5 cm long and 3-4 mm wide with dormant buds and were immersed in $0.01 \%$ (v/v) liquid detergent (Tween 80, Himedia, India) for 5 min to remove dust and dirt particles. This was followed by 5-6 washes of distilled water to remove the traces of detergent. Explants were later dipped in $0.2 \%(\mathrm{w} / \mathrm{v})$ bavistin (systemic fungicide) for $5 \mathrm{~min}$ to reduce the chances of fungal contamination, followed by washing 4-5 times in sterile distilled water. Surface sterilization of the explants was carried out under aseptic conditions in a laminar air flow. The first step of the surface sterilization was carried out using $70 \%$ ethanol (v/v) for $30 \mathrm{~s}$, followed by washing 4-5 times with sterile distilled water. Subsequently, surface sterilization was carried out using $0.075-0.1 \%(w / v)$ mercuric chloride (Himedia, India) for 5 min followed by thorough washing (6-7 times) with sterile distilled water.

\section{Culture media and culture conditions}

Murashige and Skoog (MS) liquid medium supplemented with growth regulators, ${ }^{21}$ additives (ascorbic acid $50 \mathrm{mg} / \mathrm{L}+$ citric acid 25 $\mathrm{mg} / \mathrm{L}+$ cysteine $25 \mathrm{mg} / \mathrm{L}$ ) and $3 \%$ sucrose was used for shoot induction and shoot multiplication. Modified MS (MS/4) agar gel medium supplemented with sucrose (3\%) and glucose (1\%) was used for in vitro rooting. Agar (Himedia, India) $0.6 \%$ was used as a solidifying agent. $\mathrm{pH}$ of the medium was adjusted to 6.2 for the medium containing additives and 5.8 for the rooting medium before autoclaving at $15 \mathrm{lb}$ per square inch (15 psi) for $20 \mathrm{~min}$. Cultures were maintained at $25 \pm 2^{\circ} \mathrm{C}$ with $33.78 \mu \mathrm{mol}$ photons $\mathrm{m}^{-2} \mathrm{~s}^{-1}$ light illumination for a 12 -h photoperiod and $55 \pm 5 \%$ relative humidity.

\section{Shoot initiation}

Surface sterilized explants were inoculated vertically in the Borosil culture tubes $(25 \times 150$ $\mathrm{mm}$ ) containing $10 \mathrm{~mL}$ of MS liquid medium
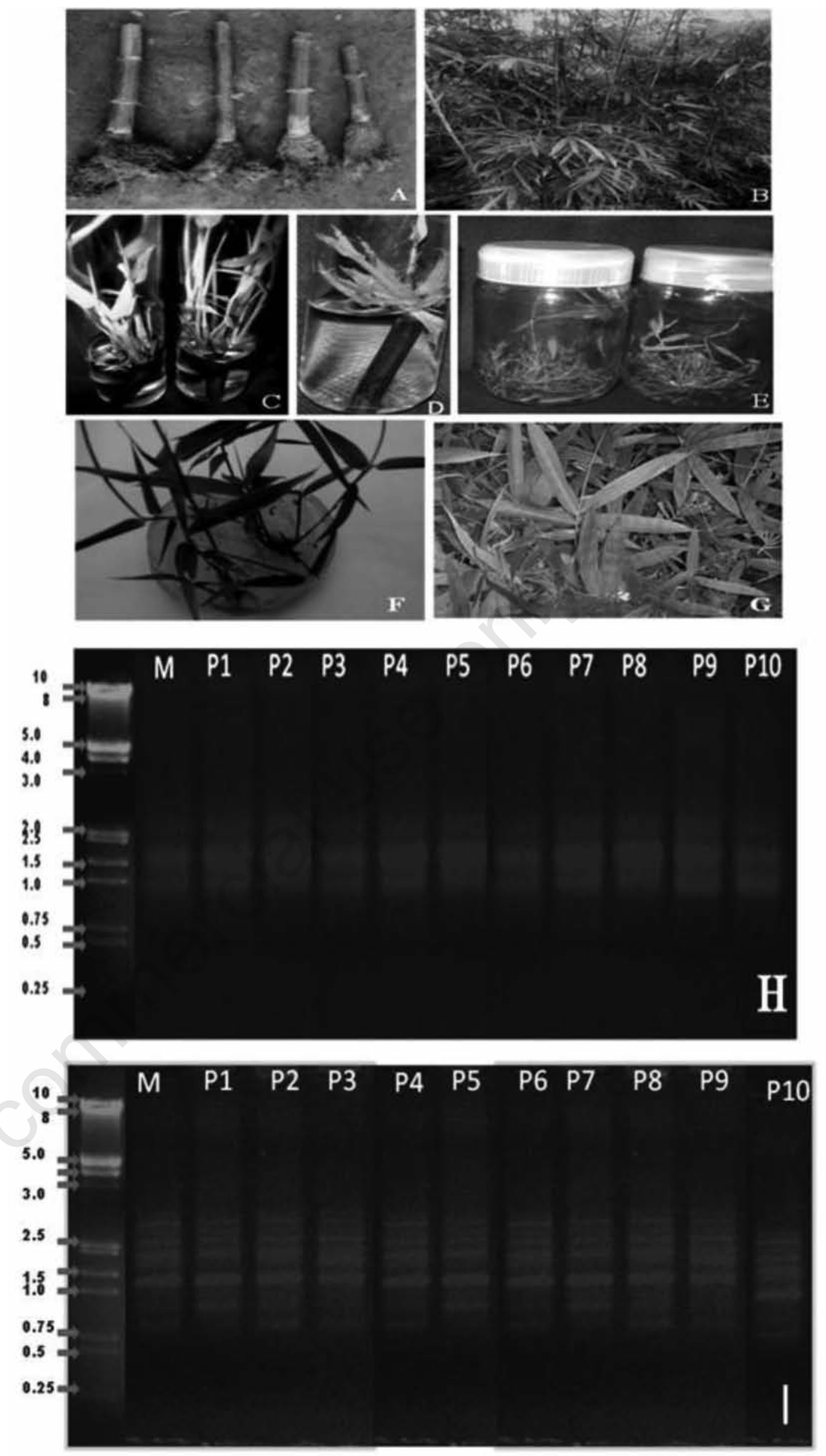

Figure 1. A) Offset cuttings of $B$. pallida collected from the germplasm bank of Rain Forest Research Institute, Jorhat.; B) Plants raised through offset cuttings in gunny bags after 30 months at IWST nursery, Bangalore; C) In vitro shoot induction in MS liquid medium supplemented with additives, NAA $1.34 \mu \mathrm{M}$ and TDZ $1.125 \mu \mathrm{M} ; \mathrm{D})$ dwarf shoots induced in the MS liquid medium supplemented with additives, NAA $0.54 \mu \mathrm{M}$ and TDZ 2.27 $\mu \mathrm{M}$; E) In vitro shoot multiplication in the MS liquid medium supplemented with additives, NAA $0.54 \mu \mathrm{M}$ and BAP $4.44 \mu \mathrm{M}$; F) In vitro root induction from the clumps pulse treated with IBA $0.5 \mathrm{mg} / \mathrm{mL}$ for 30 minutes on MS $/ 2$ medium consisting sucrose (2\%) and glucose (1\%); G) Four months old hardened plantlets of $B$. pallid; H,I) RAPD banding pattern with primers (H: OPA-02 and I: OPB-12) in both micropropagated and field grown mother plant of $B$. pallida (lane 1- marker, M- mother plant and P1-P10 progenies). 
fortified with additives and various concentrations of auxins [0.52, $1.425 \mu \mathrm{M}$ indole acetic acid (IAA) and 0.54, $1.34 \mu \mathrm{M} \alpha$-naphthalene acetic acid (NAA)] and cytokinins [benzylaminopurine (BAP) 2.22-22.2 $\mu \mathrm{M}$; Kinetin $2.325 \mu \mathrm{M}$ and $11.625 \mu \mathrm{M}$, and thiodiozuron (TDZ) 1.125-4.54 $\mu \mathrm{M}$ ]. Observations were recorded at the end of two weeks, and various parameters were taken into consideration such as: percentages of response on shoot induction, number of shoots/explant and shoot length.

\section{Shoot multiplication}

In order to optimize the growth regulators for high frequency shoot multiplication, 2.5-3.5 cm long in vitro proliferated shoot clumps (3-4 shoots/clump) were transferred to MS liquid medium supplemented with additives and cytokinins; BAP 2.22-22.2 $\mu \mathrm{M}$ and TDZ 1.125$4.54 \mu \mathrm{M}$ in combination with auxin; NAA 0.54 and $1.34 \mu \mathrm{M}$. The average number of propagule obtained from the culture after 15 days was recorded as the rate of multiplication.

\section{In vitro rooting}

For rooting, the in vitro multiplied shoots (2-3 shoot clumps, shoot length $3.0-4.0 \mathrm{~cm}$ ) were excised and pulse treated with various concentrations $(0.25-2.5 \mathrm{mg} / \mathrm{mL})$ of IBA for 30 min. The pulse-treated shoots were then transferred to half-strength MS basal salts agar gel medium consisting of sucrose $(2 \% \mathrm{w} / \mathrm{v})$ and glucose $(1 \% \mathrm{w} / \mathrm{v})$. Data were recorded after four weeks taking into consideration the parameters of rooting percentage, root number and root length.

\section{Transplantation and hardening}

In vitro rooted shoots (2-3 tillers) with shoot length 5.0-7.0 cm were carefully removed from the bottle and washed thoroughly under running tap water to remove adhered medium to the surface. Plants were then kept in $0.1 \%$ $(\mathrm{w} / \mathrm{v})$ fungicide (bavistin) for 5-10 min before being transferred to the polybags $(600 \mathrm{cc})$ containing sand, soil and compost in 4:2:4 (v/v) ratios fortified with $10 \mathrm{~kg} / \mathrm{cum}$ neem cake, 2.4 $\mathrm{kg} /$ cum single super phosphate and $0.4 \mathrm{~kg} / \mathrm{cum}$ phorate $+0.4 \mathrm{~kg} /$ cum bavistin as a prophylactic measure. Plants transplanted in polybags were kept in a polytunnel (an iron frame $2.0 \mathrm{~m}$ long and $0.6 \mathrm{~m}$ high covered with a polythene sheet) at $90 \%$ relative humidity and internal temperature $26 \pm 3^{\circ} \mathrm{C}$ for three weeks in a mist chamber. The polythene sheet was gradually removed and plants were kept in the mist chamber for one more week. Before transferring to open nursery conditions, plantlets were kept in shade $(50 \%$ in an agroshade net house) for two weeks.

\section{Genetic fidelity}

Young leaves were collected from 10 randomly selected plants regenerated through axillary shoot proliferation from the 1-year old shoot multiplication cultures and their respective mother plants for DNA extraction. Genomic DNA was extracted using the phenol chloroform method. Fresh leaf tissue $(0.2 \mathrm{~g})$ was grounded into a fine powder using liquid nitrogen in a mortar and pestle, and transferred to $5 \mathrm{~mL}$ of pre-heated extraction buffer containing 1,000 mM Tris $\mathrm{HCl}(\mathrm{pH} \mathrm{8.0)}, 1.4$ $\mathrm{mM} \mathrm{NaCl}, 20 \mathrm{mM}$ EDTA (pH 8.0), 3\% CTAB $(\mathrm{w} / \mathrm{v}), 2 \% \quad \beta$-mercaptoethanol $(\mathrm{w} / \mathrm{v})$ and $2 \%$ PVP (w/v). After proper mixing, the slurry was incubated at $65^{\circ} \mathrm{C}$ for $1 \mathrm{~h}$ by mixing thoroughly at regular time intervals and cooled to room temperature. It was then extracted with equal (1:1) volumes of phenol: chloroform and centrifuged at $12,000 \mathrm{rpm}$ for $10 \mathrm{~min}$ (Eltek Refrigerated Centrifuge RC 4100). The supernatant was transferred to a fresh tube and the phenol chloroform step was repeated until the white interphase disappeared. The aqueous phase was extracted with a chloroform: isoamyl alcohol (24:1) mixture and centrifuged at $12,000 \mathrm{rpm}$ for $10 \mathrm{~min}$. The supernatant was precipitated with 1.5-2.0 volumes of cold ethanol by incubating at $-20^{\circ} \mathrm{C}$ for $1 \mathrm{~h}$. The DNA was pelleted by centrifugation $(10,000$ rpm for $8 \mathrm{~min})$. The recovered DNA was washed with $70 \%(\mathrm{v} / \mathrm{v})$ ethanol, air dried and resuspended in $100 \mathrm{~mL}$ of TE buffer $(10 \mathrm{mM}$ Tris HCl, pH 8.0; 0.1 mM EDTA, pH 8.0) and stored at $4^{\circ} \mathrm{C}$ until use. The concentration of DNA samples was determined by an UV absorbance at $260 \mathrm{~nm}$ in a spectrophotometer (Hitachi) and also by visual observation using $0.8 \%$ agarose gel. Purity of the DNA samples was estimated by calculating the ratio of percent absorption at 260 and $280 \mathrm{~nm}$. DNA samples were adjusted to an appropriate dilution of $50 \mathrm{ng} / \mathrm{mL}$ with TE buffer. DNA sample preparation was tested for molecular weight size by agarose gel electrophoresis. Genomic DNA (10 $\mathrm{mg}$ ) was electrophoresed on horizontal $0.8 \%$ $(\mathrm{w} / \mathrm{v})$ agarose gel in $1 \mathrm{x}$ TAE buffer ( $0.04 \mathrm{M}$ Tris acetate, $0.001 \mathrm{M}$ EDTA (pH 8.0) at $75 \mathrm{~V}$ for $2 \mathrm{~h}$, gel was stained with ethidium bromide, and photographed in a gel documentation system (Herolab).

\section{Random amplified polymorphic DNA amplification}

RAPD fingerprinting was obtained by using randomly chosen arbitrary, 10-mer primers (A, $\mathrm{B}, \mathrm{E}, \mathrm{J}$ and $\mathrm{K}$ series) obtained from Operon Technologies Incorporation, Almeda, USA. Polymerase chain reaction (PCR) was performed according to the protocol of Williams $e t$ $a l .{ }^{18}$ with minor modifications. Amplification was carried out in $25 \mathrm{~mL}$ of reaction mixture containing $2.5 \mathrm{~mL}$ of $10 \mathrm{X}$ assay buffer containing $20 \mathrm{mM}$ Tris-Cl (pH 9.0), $50 \mathrm{mM} \mathrm{KCl}$ (Bangalore Genei), $220 \mu \mathrm{M}$ each of dATP, dCTP, dGTP, dTTP Bangalore Genie), $0.3 \mu \mathrm{M}$ primer, $2.5 \mathrm{mM} \mathrm{MgCl}$ (Bangalore Genei), 0.75 $\mathrm{U}$ of Taq polymerase (Bangalore Genie) and $50 \mathrm{ng}$ of template DNA. DNA amplification was carried out in an Eppendorf (Master) cycler gradient PCR programmed for: 1 cycle at $94^{\circ} \mathrm{C}$ for $3 \mathrm{~min}$, followed by 30 cycles of denaturation at $92^{\circ} \mathrm{C}$ for $30 \mathrm{~s}$, annealing at $52^{\circ} \mathrm{C}$ for 30 $\mathrm{s}$, extension at $72^{\circ} \mathrm{C}$ for $1 \mathrm{~min}$, and a final extension of $7 \mathrm{~min}$ at $72^{\circ} \mathrm{C}$.

After completion of PCR, $4 \mathrm{~mL}$ of $6 \mathrm{X}$ loading dye was added to each of the samples. The amplification products were separated according to size by electrophoresis in $1.5 \%$ agarose gel containing $0.05 \mathrm{~mL} / \mathrm{mL}$ ethidium bromide (Bangalore Genei, Bangalore) in $1 \mathrm{X}$ TAE buffer. EcoR I + Hind III double digest DNA (Fermentas) was used as the standard DNA ladder for reference. Gel was photographed under UV light. Fingerprinting with each primer was repeated at least three times. Only consistently reproducible bands were considered for data analysis. Out of 25 primers tested, 12 produced quality reproducible amplification products and these primers were selected for RAPD amplification of the mother plant and 10 randomly selected plantlets derived from axillary shoot proliferation.

\section{Experimental design and data analysis}

For shoot initiation, a minimum of 12 culture tubes were used per treatment in 3 replicates. For shoot multiplication, 3 clumps each of 3-4 shoots/clump, and for in vitro rooting, 4 clumps each with 2-3 shoots/clump, were used in 5 bottles. The experiment was repeated three times. Data were recorded after 45 days for rooting. Experiments were set up according to a completely randomized design. Variance (one way or single factor analysis) in treatment means and standard errors was determined, followed by the least significant difference (LSD) test at $\mathrm{P}=0.05$ to compare means.

DNA fingerprinting with RAPD markers was performed three times and only quality reproducible bands in the range of $350-2500$ bp were scored. DNA banding pattern generated by RAPDs was recorded as 1 for presence of band and 0 for its absence. Genetic difference between the parents and their progeny was calculated according to the RAPD marker data set as described by Ward. RAPD markers were identified by the source of primer ( $O P$ Operon), kit letter, primer number and the appropriate size in base pairs. 


\section{Results}

\section{Shoot initiation}

Nodal explants cultured on MS basal medium did not induce multiple shoots even after four weeks. Media supplemented with auxins (NAA and IAA) and cytokinins (BAP, TDZ and Kinetin) induced bud break within a week. Among the various concentrations of auxins and cytokinins tested, combination of NAA and TDZ was found to be more effective for multiple shoot induction. Maximum (4.90) shoots/responding explant with $98.52 \%$ shoot induction was obtained in the medium fortified with NAA $1.34 \mu \mathrm{M}$ along with TDZ 1.125 $\mu \mathrm{M}$ (Figure 1C). The shoots initiated at a higher concentration of BAP $(22.2 \mu \mathrm{M})$ and TDZ $(2.27 \mu \mathrm{M})$ along with NAA $1.34 \mu \mathrm{M}$ (Figure 1D) were dwarf and were not suitable for further shoot multiplication or rooting. In general, shoot length was longer in medium with BAP/TDZ + NAA than with BAP/TDZ + IAA. The highest $(5.11 \mathrm{~cm})$ shoot length was obtained in hormone-free medium (Table 1).

\section{Shoot multiplication}

Among the two cytokinins (BAP and TDZ) tested, BAP was found to be ideal for ensuring quality of shoot multiplication. NAA with BAP/TDZ in the medium had a significant effect on shoot multiplication. A higher concentration $(1.34 \mu \mathrm{M})$ of NAA along with BAP proved to be the best in terms of shoot number and shoot length. Shoot number increased along with increasing concentrations of BAP $(2.22-22.2 \mu \mathrm{M})$ and TDZ (1.125-4.54 $\mu \mathrm{M})$. Medium consisting of NAA $1.34 \mu \mathrm{M}$ and BAP $22.2 \mu \mathrm{M}$ produced the highest number of shoots: 8.05 shoots/clump. But these shoots were dwarf and vitrified with condensed nodes that were not suitable for further multiplication. Therefore, NAA (1.34 $\mu \mathrm{M})$ with BAP (4.44 $\mu \mathrm{M})$ was found to be ideal for shoot multiplication, with an average 6.34 shoots/clump with shoot length of $4.5 \mathrm{~cm}$ in the 2 -week period (Table 2 and Figure 1E).

\section{In vitro rooting}

Lower concentration $(0.25 \mathrm{mg} / \mathrm{mL}$ and 0.5 $\mathrm{mg} / \mathrm{mL}$ ) of IBA enhanced rooting percentage, root number and root length.

Maximum (67.5\%) rooting with highest (5.36) root number and root length $(5.97 \mathrm{~cm})$ was obtained from the plants pulse-treated with IBA $(0.5 \mathrm{mg} / \mathrm{mL})$ for $30 \mathrm{~min}$ (Figures 2A,B,F) followed by those pulse-treated with IBA $0.25 \mathrm{mg} / \mathrm{mL}$. Increased concentrations (1 $\mathrm{mg} / \mathrm{mL}$ and $2.5 \mathrm{mg} / \mathrm{mL}$ ) not only decreased the rooting percentage, but also decreased root number and root length.

The plants with reduced root length did not survive hardening.

\section{Transplantation and hardening}

The method that involved keeping plants in a polytunnel in a greenhouse for an initial three weeks followed by one week in a greenhouse and two weeks in shade (50\%) proved the most suitable with a high rate (>95\%) of plant survival. Within four months after hardening, the plants produced 3-4 tillers growing to a height of $25-30 \mathrm{~cm}$ with miniature rhizome (Figure 2G). During hardening, leaves turned green with a healthy appearance and expansion of the leaf lamina.

Table 1. Effect of plant growth regulators on high frequency shoot induction from the nodal shoot segments of $B$. pallida in Murashige and Skoog liquid medium supplemented with additives.

\begin{tabular}{|c|c|c|c|c|}
\hline Treatments & Plant growth regulators $(\mu \mathrm{M})$ & $\%$ of response & No. of shoots/explant* & Shoot length $(\mathrm{cm})$ \\
\hline $\mathrm{T} 1$ & Control & $21.77 q$ & $1.01 \mathrm{kl}$ & $5.11 \mathrm{a}$ \\
\hline $\mathrm{T} 2$ & NAA $0.54+B A P 2.22$ & $42.13 n$ & $1.35 \mathrm{j}$ & $5.00 \mathrm{a}$ \\
\hline T3 & IAA $0.52+$ BAP 2.22 & 38.340 & $1.12 \mathrm{k}$ & $4.81 \mathrm{~b}$ \\
\hline T4 & NAA 0.54+BAP 4.44 & $95.5 \mathrm{~d}$ & $1.40 \mathrm{j}$ & $4.61 \mathrm{~b}$ \\
\hline $\mathrm{T} 5$ & IAA $0.52+$ BAP 4.44 & $43.56 \mathrm{~m}$ & $1.19 \mathrm{k}$ & $3.92 \mathrm{e}$ \\
\hline T6 & NAA 0.54+BAP 11.1 & $98.10 \mathrm{~b}$ & $3.79 \mathrm{~d}$ & $4.53 \mathrm{c}$ \\
\hline $\mathrm{T} 7$ & IAA $0.52+$ BAP 11.1 & $80.32 \mathrm{i}$ & $1.95 \mathrm{i}$ & $3.47 \mathrm{f}$ \\
\hline T8 & NAA 1.34+BAP 4.44 & $96.89 \mathrm{c}$ & $2.79 \mathrm{e}$ & $4.66 \mathrm{~b}$ \\
\hline $\mathrm{T} 9$ & IAA $1.425+$ BAP 4.44 & 82.17h & $2.30 \mathrm{~h}$ & $3.69 \mathrm{e}$ \\
\hline $\mathrm{T} 10$ & NAA 1.34+BAP 11.1 & $98.11 \mathrm{~b}$ & $2.50 \mathrm{~g}$ & $4.22 \mathrm{~d}$ \\
\hline $\mathrm{T} 11$ & IAA $1.425+$ BAP 11.1 & $87.42 \mathrm{~g}$ & $2.56 \mathrm{~g}$ & $3.58 \mathrm{f}$ \\
\hline $\mathrm{T} 12$ & NAA $1.34+B A P 22.2$ & $98.57 \mathrm{a}$ & $4.01 \mathrm{c}$ & $2.37 \mathrm{i}$ \\
\hline $\mathrm{T} 13$ & IAA $1.425+$ BAP 22.2 & $87.64 \mathrm{f}$ & $2.71 \mathrm{f}$ & $1.23 \mathrm{i}$ \\
\hline $\mathrm{T} 14$ & NAA 0.54+BAP 2.22+Kin 2.325 & $60.36 \mathrm{j}$ & $1.52 \mathrm{j}$ & $1.02 \mathrm{k}$ \\
\hline $\mathrm{T} 15$ & NAA 0.54+Kin 11.625 & $41.91 n$ & $1.81 \mathrm{i}$ & $2.11 \mathrm{j}$ \\
\hline T16 & NAA 0.54+TDZ 4.54 & $32.33 p$ & $2.91 \mathrm{e}$ & $1.91 \mathrm{j}$ \\
\hline $\mathrm{T} 17$ & NAA 0.54+TDZ 2.27 & $50.31 \mathrm{k}$ & $4.59 \mathrm{~b}$ & $2.25 \mathrm{i}$ \\
\hline T18 & IAA $0.52+$ TDZ 2.27 & 49.521 & $2.78 \mathrm{ef}$ & $2.15 \mathrm{i}$ \\
\hline T19 & NAA 0.54+TDZ 1.125 & $95.00 \mathrm{e}$ & $4.61 \mathrm{~b}$ & $3.07 \mathrm{~g}$ \\
\hline T20 & IAA 0.52+TDZ 1.125 & $82.33 \mathrm{~h}$ & $2.85 \mathrm{e}$ & $2.80 \mathrm{~h}$ \\
\hline $\mathrm{T} 21$ & NAA 1.34+TDZ 1.125 & $98.52 \mathrm{a}$ & $4.90 \mathrm{a}$ & $3.11 \mathrm{lg}$ \\
\hline \multirow[t]{3}{*}{$\mathrm{T} 22$} & IAA 1.425+TDZ 1.125 & $87.70 \mathrm{f}$ & $2.96 \mathrm{e}$ & 4.08d \\
\hline & SE $(0.05)$ & 0.16 & 0.10 & 0.34 \\
\hline & $\mathrm{CD}(0.05)$ & 0.26 & 0.17 & 0.23 \\
\hline
\end{tabular}

Treatments followed by different letters are significantly different from each other. SE, standard error of the mean; CD, Critical difference at $\infty=0.05$; BAP, benzylaminopurine; IAA, indole acetic acid; NAA, $\alpha$-naphthalene acetic acid; TDZ thiodiozuron. *mean number of 12 replicates. 


\section{Genetic fidelity}

No morphological variation was seen in the micropropagated plants of the $B$. pallida. Out of the 25 decamer RAPD primers initially screened, 12 oligonucleotides produced clear and discernable amplification products. The products were also monomorphic across all the micro-propagated plants. The number of bands produced by a single primer ranged from 3 (OPA-02) to 9 (OPB-12) (Figures 2H, I). A total of 181 bands were produced with an average frequency of 6 bands per primer. The amplified products ranged in size from $250 \mathrm{bp}$ to $4200 \mathrm{bp}$. RAPD fingerprints of all primers used revealed no variation in micro-propagated plants of $B$. pallida.

\section{Discussion}

A long flowering cycle and sporadic flowering lead to non-availability of seed as and when required for afforestation and establishment of bamboo plantations. Propagation of bamboo through offset cuttings, rhizome splitting, air layering, culm cuttings and culm branch cuttings are the traditional methods of vegetative propagation. These methods are limited by the short period of availability of cuttings at the appropriate stage, the low rate of rooting from culm and branch, the need for bulk quantities of material and also the potentially small-scale production. For large scale production of clonal planting material, tissue culture is the only reliable method. ${ }^{7}$ Micropropagation of bamboo species from the explants of field grown clumps have been reported in a few species but there have been no reports on the evaluation of genetic fidelity of micro-propagated bamboo plants by molecular markers. MS liquid medium supplemented with additives, TDZ $1.125 \mu \mathrm{M}$ and NAA $1.34 \mu \mathrm{M}$ proved to be the best combination for high-frequency multiple shoot induction. Superiority of TDZ over BAP for multiple shoot induction was also reported in $B$. edulis. ${ }^{22}$ Higher concentrations of cytokinins resulted in a greater number of shoots. However, shoots were dwarf with more leaves which is found to agree with the result obtained by Arya and Sharma in B. bambos, ${ }^{23}$ whereas in B. wamin, a higher concentration $(22.2 \mu \mathrm{M})$ of BAP in MS medium favored highfrequency $(83.33 \%)$ bud breaks. ${ }^{24}$ The problem of phenolic exudation at the cut ends of explants which leads to the eventual death of initiated shoots is the main problem associated with adult bamboo tissues. This problem was overcome in Arundinaria callosa by correct removal of brown leaf sheaths and quick transfer to fresh medium whenever browning appeared. ${ }^{25}$ The present protocol differs significantly in that addition of additives in the cul-
Table 2. Effect of plant growth regulators on shoot multiplication and growth from shoot clumps of $B$. pallida in Murashige and Skoog liquid medium supplemented with additives.

\begin{tabular}{|c|c|c|c|}
\hline T. No. & PGRs ( $\mu$ M) & No. of shoots/Clump & Shoot length (cm) \\
\hline 1 & $\mathrm{HF}$ & $3.10 \mathrm{~h}$ & $5.32 \mathrm{a}$ \\
\hline 2 & NAA 0.54+BAP 2.22 & $3.30 \mathrm{~h}$ & $4.56 \mathrm{~b}$ \\
\hline 3 & NAA 0.54+BAP 4.44 & $4.20 \mathrm{~g}$ & $4.47 \mathrm{~b}$ \\
\hline 4 & NAA 0.54+BAP 11.1 & $4.50 \mathrm{f}$ & $3.82 \mathrm{c}$ \\
\hline 5 & NAA $0.54+B A P 22.2$ & $4.80 \mathrm{e}$ & $3.57 \mathrm{~d}$ \\
\hline 6 & NAA 1.34+BAP 2.22 & $5.00 \mathrm{e}$ & $4.63 \mathrm{~b}$ \\
\hline 7 & NAA 1.34+BAP 4.44 & $6.34 \mathrm{c}$ & $4.50 \mathrm{~b}$ \\
\hline 8 & NAA $1.34+$ BAP 11.1 & $7.00 \mathrm{~b}$ & $4.10 \mathrm{c}$ \\
\hline 9 & NAA 1.34+BAP 22.2 & $8.05 \mathrm{a}$ & $3.78 \mathrm{c}$ \\
\hline 10 & NAA 0.54+TDZ 1.125 & $4.18 \mathrm{~g}$ & $4.51 \mathrm{~b}$ \\
\hline 11 & NAA 0.54+TDZ 2.27 & $4.46 \mathrm{f}$ & $3.72 \mathrm{c}$ \\
\hline \multirow[t]{3}{*}{12} & NAA 0.54+TDZ 4.54 & $5.37 \mathrm{~d}$ & $2.43 \mathrm{e}$ \\
\hline & SE $(0.05)$ & 0.12 & 0.26 \\
\hline & $\mathrm{CD}(0.05)$ & 0.22 & 0.43 \\
\hline
\end{tabular}

Treatments followed by different letters are significantly different from each other. SE, standard error of the mean; CD, Critical difference at $\infty=0.05$; BAP, benzylaminopurine; IAA, indole acetic acid; NAA, $\alpha$-naphthalene acetic acid; TDZ thiodiozuron.
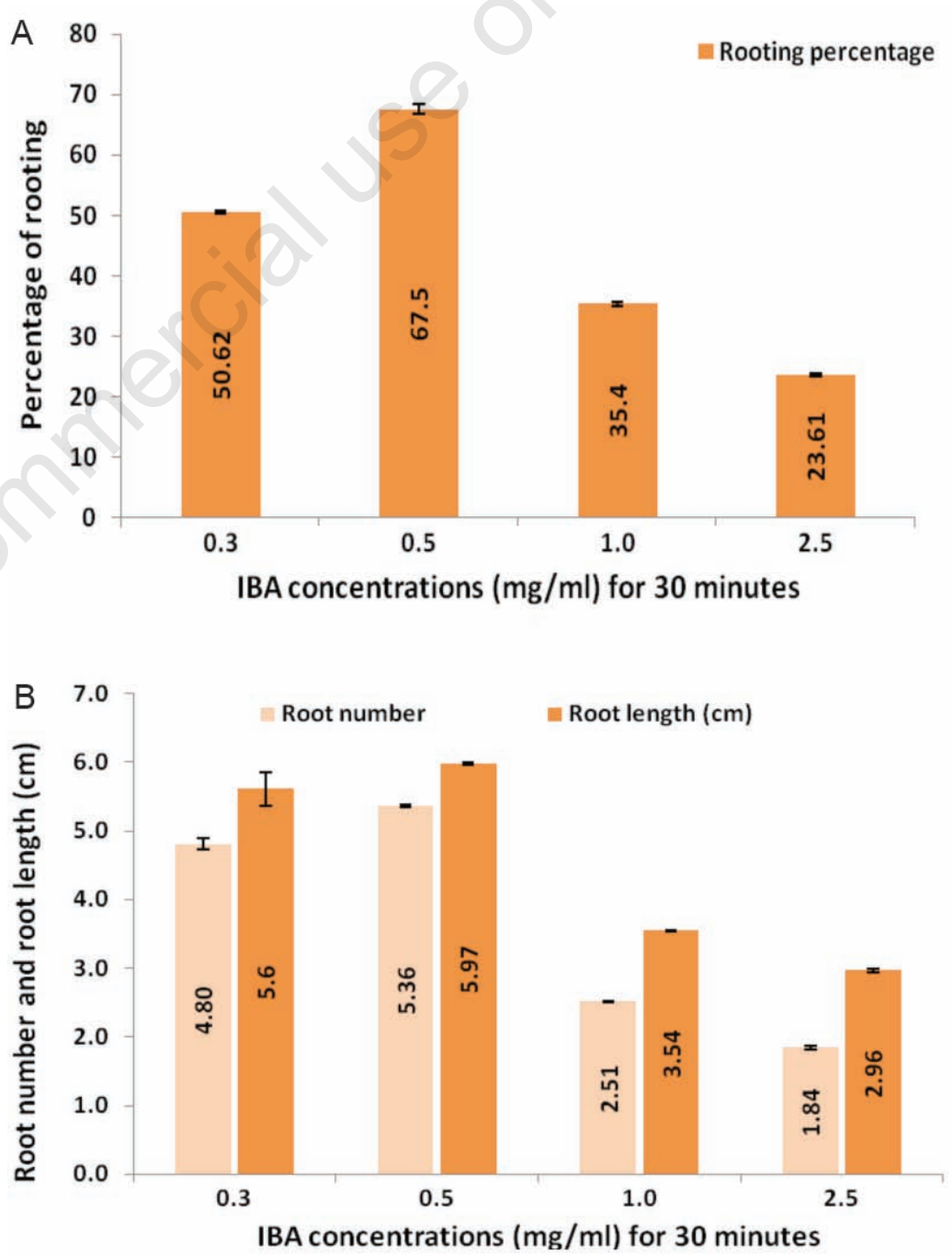

Figure 2. A) Effect of various concentrations of IBA pulse treatment for 30 minutes on in vitro rooting percentage from shoot clumps of B.pallida; B) Root Effect of various concentrations of IBA pulse treatment for 30 minutes on in vitro rooting (root number and root length) from shoot clumps of $B$. pallida. 
ture medium helped to overcome leaching.

Research carried out on micropropagation of bamboo showed variation in species in response to levels of BAP for shoot multiplication. ${ }^{25,26}$ MS liquid medium consisting of additives, NAA $1.34 \mu \mathrm{M}$ and BAP $4.44 \mu \mathrm{M}$ helped to further multiplicate B.pallida. Similary, the synergetic effect of NAA $1.34 \mu \mathrm{M}$ and BAP 4.44 $\mu \mathrm{M}$ in MS liquid medium favored better shoot multiplication in $P$. stocksii. ${ }^{13,14}$ This clearly indicates that, though the growth regulators are the same, their endogenous concentrations and exogenous requirement varies with the species. A serious problem that prevents the successful micropropagation of bamboo and other woody species is difficulty in rooting that was also observed in $B$. pallida. ${ }^{27,28}$ The induction of rooting in many bamboo species requires many additives, such as coumarin, phloroglucinol and TDZ, particularly when the explant is taken from the nodal segments of adult plants. ${ }^{26,29}$ In $B$. wamin, $B$. nutan and $T$. spathiflorus, rooting was achieved by IBA treatments of shoots for three days, four weeks and two weeks, respectively, before transferring to the MS/2 medium-consisting sucrose. . $4,30,31^{2}$ But in B. pallida, well developed shoots when pulse-treated with IBA $0.5 \mathrm{mg} / \mathrm{mL}$ for $30 \mathrm{~min}$ were rooted on the MS half-strength plant growth hormone medium consisting of both sucrose (2\%) and glucose (1\%) in 4-5 weeks at $25 \pm 1^{\circ} \mathrm{C}$ and $33.78 \mu \mathrm{mol}$ photons $\mathrm{m}^{-2} \mathrm{~s}^{-1}$ light for a 12-h photoperiod. The two-step protocol followed in the present study resulted in excellent rooting in a basal medium without any additives. It is not advisable to let the roots grow too long as this increases the probability of root damage during transplantation. Also, roots frequently die after transplantation and new roots must then develop in vivo if the plants are to survive. ${ }^{32,33}$ A maximum $100 \%$ survivability was achieved in micro-propagated plant of Thamnocalamus spathiflorus with root length $3.14 \mathrm{~cm}$ and survivability reduced to $60 \%$ when root length decreased to $1.84 \mathrm{~cm}^{34}$ In the present study, plants with root length less than $2 \mathrm{~cm}$ did not survive after transplantation.

The initial 3-week period in which plants were kept in a polytunnel in a mist chamber followed by two weeks in $50 \%$ shade proved the most suitable for a high rate (>95\%) of plant survival. RAPD markers have been used to study the genetic variation of micro-propagated plants in many other plant species. ${ }^{35,36}$ Distinct polymorphism was observed in the micro-propagated plants of 2 clones of Populus deltoids ${ }^{37}$ whereas in $B$. pallida the present investigation based on RAPD markers revealed no genetic variation in the micro-propagated plants of $B$. pallida compared to the mother plant.

\section{Conclusions}

This investigation presents a detailed protocol for successful rapid clonal propagation of $B$. pallida, an economically important and edible bamboo from nodal explants of adult plant. High multiplication efficiency, good rooting, excellent establishment in the soil and normal growth performance of micro-propagated plants without genetic variation, as reported in this study, are the necessary requisites for the industrial adoption of in vitro propagation technology for large-scale production.

\section{References}

1. Singhal RM, Gangopadhyay PB. Bamboos in India and data base. Dehra Dun: Publication Division, Indian Council of Forestry Research and Education; 1999. p. 147.

2. Anonymous. National mission on bamboo technology and trade development. New Delhi: Planning Commission, Government of India; 2003. p. 176.

3. Baruah BK, Das B, Haque A, et al. Iron removal efficiency of different bamboo charcoals: a study on modified indigenous water filtration technique in rural areas of Assam. J Chem Pharm Res 2011;3:454-9.

4. Arunachalam K, Upadhyaya K, Arunachalam A. Foliage decomposition and nutrient release dynamics of Bambusa balcooa and Bambusa pallida in a 9-year-old jhum fallow. J Bamboo Rattan 2005;4:4154.

5. Mc Clure FA. The Bamboos a fresh perspective. Cambridge: Harvard University Press; 1966. p. 347.

6. Nath M, Phukan U, Barua G, et al. Propagation of certain bamboo species from chemically treated culm cuttings. Ind For 1986;9:151-6.

7. Geilis J, Peeters H, Deberg PC. Tissue culture strategies for genetic improvement of bamboo. Acta Horticulture 2002;552:195203.

8. McCown DD, McCown BH. North American hardwoods Case histories: gymnosperms, angiosperms and palms. In: Bonga JM, Durzan DJ. Cell and tissue culture in forestry. Dordrecht: Martinus Nijhoff Publishers; 1987. pp. 247-260.

9. Beniwal BS, Singh NB. Bamboo improvement works in Arunachal Pradesh. Ind For 1988;116:549-59.

10. Chaturvedi HC, Sharma M, Sharma AK. In vitro regeneration of Dendrocalamus strictus Nees through nodal segment taken from field grown culm. Plant Sci 1993; 91:97-101.
11. Mukuntha Kumar S, Mathur J. Artificial seed production in the male bamboo Dendrocalamus strictus L. Plant Sci 1992;87:109-13.

12. Ramanayake SMSD, Wanniarachchi WAVR, Tennakoon TMA. Axillary shoot proliferation and in vitro flowering in an adult giant bamboo, Dendrocalamus giganteus Wall. Ex Munro. In Vitro Cell Dev Biol Plant 2001;37:667-71.

13. Sanjaya Rathore TS, Ravi Shankar Rai V. Micropropagation of Pseudoxytenanthera. Stocksii Munro. In Vitro cell Dev Biol Plant 2005;41:333-7.

14. Somashekar PV, Rathore TS, Shashidhar KS. Rapid and simplified method of micropropagation of Pseudoxytenanthera stocksii. In: Ansari SA, Narayanan C, Mandal AK. Forest biotechnology in India. Delhi: Satish serial publishing house; 2008. pp. 165-182.

15. Das M, Pal A. In vitro regeneration of Bambusa balcoa Roxb. Factors affecting changes of morphogenetic competence in the axillary buds. Plant Cell Tiss Org Plant 2005;81:109-12.

16. Victor MJ, Jhamna C, Elena T, et al. In vitro propagation of the neotropical giant bamboo, Guadua angustifolia Kunth, through axillary shoot proliferation Plant Cell Tiss and Org Cul 2006;86:389-95.

17. Shirin F, Rana PK. In vitro plantlet regeneration from nodal explants of field-grown culms in Bambusa glaucescens Wild. Plant Biotec Rep 2007;1:141-7.

18. Williams JGK, Kubelik AR, Livak KJ, et al. DNA polymorphisms amplified by arbitrary primers are useful as genetic markers. Nucleic Acids Res 1990;18:6531-5.

19. Rout GR and Das G. An assessment of genetic integrity of micropropagated plants of Plumbago zeylarica by RAPD markers. Biol Plantarum 2002;45:23-7.

20. Martins M, Sarmento D, Oliveira MM. Genetic stability of micropropagated almond plantlets, as assessed by RAPD and ISSR markers. Plant Cell Rep 2004;23:4926.

21. Murashige T, Skoog F. A revised medium for rapid growth and bioassay with tobacco tissue cultures. Physiology Plant 1962;15: 473-97.

22. Lin CS, Chang WC. Micropropagation of Bambusa edulis through nodal explants of field grown culms and flowering of regenerated plantlets. Plant Cell Rep 1998;17: 617-20.

23. Arya S, Sharma S. Micropropagation technology of Bambusa bambos through shoot proliferation. Ind For 1998;124:725-31.

24. Arshad SM, Kumar A, Bhatnagar SK. Micropropagation of Bambusa wamin through shoot proliferation of mature nodal explants. J of Biol Res 2005;3:59-66. 
25. Sayanika DW, Sharma GJ. In Vitro propagation of Arundinaria callosa Munro- an Edible Bamboo from nodal explants of mature plants. Open Plant Sci J 2009;3:359.

26. Ramanayake SMSD, Yakandawala K. Micropropagation of the giant bamboo (Dendrocalamus giganteus Munro.) from nodal segments taken from field grown culms. Plant Sci 1997;129:213-23.

27. Nemeth G. Induction of rooting, biotechnology in agriculture and forestry trees. Berlin, Heidelberg: Springer-Verlag; 1986. pp. 49-64.

28. Gielis J, Peeters H, Gillis K, et al. Tissue culture strategies for genetic improvement of bamboo. Acta Hortic 2001;552:1952003.

29. Ramanayake SMSD, Meemaduma VN, Weerawardene TE. In vitro shoot prolifera- tion and enhancement of rooting for the large-scale propagation of yellow bamboo (Bambusa vulgaris Striata). Sci Hortic 2006;110:109-13.

30. Yasodha R, Kamala S, Anand Kumar SP, et al. Effect of glucose on in vitro rooting of mature plants of Bambusa nutans. Sci Hortic 2008;116:113-6.

31. Bag N, Chandra S, Palani LMS, Nandi SK. Micropropagation of Devringal (Thamnocalamus spathiflorus (Trin) Munro) - a temperate bamboo and comparison between in vitro propagated plants and seedlings. Plant Sci 2000;156:125-35.

32. Davis MJ, Baker R Hanan JJ.. Clonal multiplication of Carnation by micropropagation. J Amer Soc Hort Sci 1977;102:48-53.

33. Debergh PE, Maene LJ. A scheme for commercial propagation of ornamental plants by tissue culture. Sci Hort 1981;14:335-45.
34. Niladri B, Suman C, Palni LMS, Nandi SK. Micropropagation of Dev-ringal [Thamnocalamus spathiflorus (Trin.) Munro] - a temperate bamboo, and comparison between in vitro propagated plants and seedlings. Plant Sci 2000;156:125-35.

35. Shu QY, Liu GS, Qi DM, et al. An effective method for axillary bud culture an RAPD analysis of cloned plants in tetraploid black locust. Plant Cell Rep 2003;22:175-80.

36. Salvi ND, George L, Susan E. Micropropagation and field evaluation of micropropagated plants of turmeric. Plant Cell, Tis Org Cul 2002;68:143-51.

37. Rani V, Parida A, Raina SN. Random amplified polymorphic DNA (RAPD) markers for genetic analysis in micropropagated plants of Populus deltoids Marsh. Plant Cell Rep 1995;14:459-62. 